\title{
Effect of nalbuphine on intrabiliary pressure in the early postoperative period
}

The effect of nalbuphine on common bile duct ( $C B D$ ) pressure was studied by measurements through $T$-tubes on the first and second postoperative days after cholecystectomy and choledochotomy. Nalbuphine in a dose of $0.25 \mathrm{mg} \cdot \mathrm{kg}^{-1}$ was injected intramuscularly in 11 patients, and changes in biliary pressure, heart and respiratory rate, blood pressure, and arterial blood gases were recorded during the subsequent four hours. The patients were free of pain, had stable common bile duct pressures and did not have any statistically significant changes in their vital signs. These results are similar to our previous observations during perioperative intravenous injection of nalbuphine. It is suggested that nalbuphine does not significantly change, or even may relax, the sphincter of Oddi, and can therefore be recommended as a safe analgesic in the postoperative period after extrahepatic biliary surgery.

Key words

ANALGESICS: nalbuphine; GASTROINTESTINAL TRACT: common bile duct pressure.

From the Departments of Anesthesiology and General Surgery, Hadassah University Hospital, Mount Scopus, Jerusalem, Israel.

Address correspondence to: Dr. E. Vatashsky, Department of Anesthesiology, Hadassah University Hospital, Mount Scopus, POB 24035, Jenusalem 91240, Israel.
Cholecystectomy produces severe postoperative pain $^{1}$ that necessitates the administration of potent analgesic drugs. Intramuscular injection of narcotics is the most common practice for postoperative pain relief. ${ }^{2}$ Although morphine, meperidine, fentanyl and other narcotics relieve the pain of biliary colic they all cause a consistent elevation of CBD pressures both in animals and in man. ${ }^{2-4}$ Moreover, there were published reports that these drugs can also produce biliary colic. ${ }^{5,6}$ Recently it was shown that nalbuphine hydrochloride administered intravenously in anaesthetized patients during cholecystectomy, does not significantly change the intrabiliary pressure. ${ }^{7,8}$ The present study explores the use of nalbuphine for control of pain after cholecystectomy and choledochotomy and its effect on intrabiliary pressure.

\section{Methods}

All patients gave informed consent according to the institutional policy, and the study was approved by the Ethics Committee.

The study was conducted in 11 otherwise healthy (ASA physical status I) patients (five men and six women) with an average age of 54.7 years (range 39 to 73 ) and mean weight $68.4 \mathrm{~kg}$ (range 57 to 84 ). They were studied during the first and second postoperative days following cholecystectomy and insertion of a T-tube into the common bile duct when choledochotomy was performed..$^{9}$ All patients were admitted with a diagnosis of cholelithiasis, and referred for cholecystectomy and intraoperative cholangiography. In all cases an abnormal cholangiogram was an indication for common bile duct exploration.

No drugs were administered for 12 hours before the operation. Premedication consisted of diazepam 5-10 mg P.O. one hour before operation. Anaesthesia was carried out with thiopentone, pancuron- 
TABLE I Results, Day 1. Effects of IM Nalbuphine (mean ISD)

\begin{tabular}{|c|c|c|c|c|c|c|c|}
\hline $\begin{array}{l}\text { Time } \\
\text { after } \\
\text { injection } \\
\text { (minutes) }\end{array}$ & $\begin{array}{l}C B D \text { pressure } \\
\left(\mathrm{cm} \mathrm{H}_{2} \mathrm{O}\right)\end{array}$ & $\begin{array}{l}\text { Pulse rate } \\
\text { (beatsimin) }\end{array}$ & $\begin{array}{l}\text { Respiratory } \\
\text { rate } \\
\text { (breaths'min) }\end{array}$ & $\begin{array}{l}\text { Mean } \\
\text { arterial } \\
\text { blood } \\
\text { pressure } \\
\text { (mmHg) }\end{array}$ & $\begin{array}{l}\mathrm{PaO}_{2} \\
(\mathrm{mmHg})\end{array}$ & $\begin{array}{l}\mathrm{PaCO}_{2} \\
(\mathrm{mmHg})\end{array}$ & $p H$ \\
\hline 0 & $13.2 \pm 3.1$ & $92 \pm 21$ & $26 \pm 7$ & $97 \pm 15$ & $84 \pm 5.4$ & $43 \pm 2.4$ & $7.42 \pm 0.02$ \\
\hline $15^{\prime}$ & $14.3 \pm 4.2$ & $90 \pm 17$ & $26 \pm 6$ & $95 \pm 16$ & $83 \pm 5.6$ & $43 \pm 2.4$ & $7.42 \pm 0.01$ \\
\hline $30^{\prime}$ & $13.4 \pm 2.1$ & $84 \pm 14$ & $23 \pm 6$ & $91 \pm 13$ & $84 \pm 7.3$ & $42 \pm 2.2$ & $7.42 \pm 0.01$ \\
\hline $45^{\prime}$ & $13.1 \pm 2.2$ & $84 \pm 11$ & $21 \pm 5$ & $91 \pm 12$ & $87 \pm 6.7$ & $41 \pm 2.3$ & $7.40 \pm 0.02$ \\
\hline $60^{\prime}$ & $14.3 \pm 3.6$ & $84 \pm 12$ & $22 \pm 6$ & $90 \pm 14$ & $86=7.5$ & $40 \pm 1.6$ & $7.40 \pm 0.01$ \\
\hline $90^{\prime}$ & $13.2 \pm 3.4$ & $83 \pm 10$ & $22 \pm 6$ & $91 \pm 13$ & $85 \pm 6.4$ & $40 \pm 1.5$ & $7.40 \pm 0.01$ \\
\hline $120^{\prime}$ & $11.5 \pm 3.2$ & $83 \pm 11$ & $21 \pm 5$ & $90 \pm 12$ & $85 \pm 7.2$ & $41 \pm 1.6$ & $7.40 \pm 0.02$ \\
\hline $150^{\prime}$ & $12.5 \pm 3.3$ & $84 \pm 10$ & $21 \pm 5$ & $90 \pm 11$ & $84 \pm 5.6$ & $41 \pm 2.4$ & $7.41 \pm 0.01$ \\
\hline $180^{\prime}$ & $12.3 \pm 4.5$ & $84 \pm 11$ & $23 \pm 7$ & $92 \pm 13$ & $83 \pm 6.4$ & $41 \pm 2.1$ & $7.41 \pm 0.01$ \\
\hline $210^{t}$ & $12.1 \pm 3.5$ & $85 \pm 11$ & $23 \pm 8$ & $93 \pm 11$ & $83 \pm 7.3$ & $42 \pm 1.3$ & $7.41 \pm 0.03$ \\
\hline $240^{\prime}$ & $12.2 \pm 3.4$ & $85 \pm 13$ & $24 \pm 7$ & $93 \pm 14$ & $82 \pm 6.7$ & $42 \pm 1.9$ & $7.41 \pm 0.02$ \\
\hline
\end{tabular}

ium, nitrous oxide-oxygen (7:3) and halothane. Succinylcholine was excluded to prevent its relaxation effect on the sphincter of Oddi. ${ }^{10}$

At the end of the operation, the T-tube was brought out through the abdominal wall for drainage of bile and was used for measuring CBD pressure, as described in a previous report. ${ }^{8}$ Briefly, the method of intrabiliary pressure measurements was as follows: the distal end of the T-tube was perfused with 0.9 per cent saline solution by means of an infusion pump (Harvard, Model 933) at a rate of $1 \mathrm{ml} /$ minute. Intraluminal pressure was transmitted through the saline-filled catheter and threeway stopcock and recorded in on a VR-6 Simultrace Recorder (Elecronics for Medicine, Inc.). The zero mark of the recorder was adjusted at the level of mid-axillary line, and maintained there for the entire set of measurements. After the CBD pressure had stabilized for 20 minutes (control values) the study commenced.

Nalbuphine $0.25 \mathrm{mg} \cdot \mathrm{kg}^{-1}$ was injected intramuscularly, and changes in intrabiliary pressure were recorded every five minutes in the first hour and every 15 minutes during the next three hours. Each patient was studied twice: first, eight hours after the end of the surgery and secondly, 24 hours later, when the patient was complaining of pain. ECG and pulse rate were recorded continuously (Mennen Medical Monitor), mean arterial blood pressure was measured every two minutes (Sentron automatic blood pressure monitor), and respiratory rate was measured visually. Arterial blood samples were withdrawn for blood gas analysis. All data were noted at the above-mentioned intervals. Side effects such as nausea or vomiting were noted according to the patients' complaints. Statistical analysis of the data was performed using ANOVA (Analysis of variance), and a $\mathrm{p}$ value $<0.05$ was regarded as significant. Values presented are expressed as means $\pm \mathrm{SD}$.

\section{Results}

The data for CBD pressure, mean arterial blood pressure, pulse and respiratory rates, and arterial blood gases are shown in Tables I and II. Nalbuphine, injected intramuscularly, resulted in a clinically acceptable relief of pain in all surgical patients which lasted throughout the four hours of investigation. The drug caused a small but statistically insignificant fall in mean arterial pressure and heart rate. The respiratory rate also decreased, with simultaneous improvement in arterial blood gases values, but these changes were not significant. The common bile duct pressure slowly decreased from $13.2 \pm 3.1$ to $12.3 \pm 3.4 \mathrm{~cm} \mathrm{H}_{2} \mathrm{O}$ on the first postoperative day, and from $15.2 \pm 4.1$ to $13.5 \pm$ $3.6 \mathrm{~cm} \mathrm{H}_{2} \mathrm{O}$ on the second postoperative day, but these changes were not statistically significant. After nalbuphine was given, all patients were sufficiently awake to converse intelligently, and were able to move themselves. None complained of nausea, vorniting or other side effects.

\section{Discussion}

The ideal analgesic drug for the management of 
TABLE II Results, Day 2. Effects of IM Nalbuphine (mean \pm SD)

\begin{tabular}{|c|c|c|c|c|c|c|c|}
\hline $\begin{array}{l}\text { Time } \\
\text { after } \\
\text { injection } \\
\text { (minutes) }\end{array}$ & $\begin{array}{l}\mathrm{CBD} \text { pressure } \\
\left(\mathrm{cm} \mathrm{H}_{2} \mathrm{O}\right)\end{array}$ & $\begin{array}{l}\text { Pulse rate } \\
\text { (beats/min) }\end{array}$ & $\begin{array}{l}\text { Respiratory } \\
\text { rate } \\
\text { (breaths/min) }\end{array}$ & $\begin{array}{l}\text { Mean } \\
\text { arterial } \\
\text { blood } \\
\text { pressure } \\
\text { (mmHg) }\end{array}$ & $\begin{array}{l}\mathrm{PaO}_{2} \\
(\mathrm{mmHg})\end{array}$ & $\begin{array}{l}\mathrm{PaCO}_{2} \\
(m m \mathrm{Hg})\end{array}$ & $p H$ \\
\hline 0 & $15.2 \pm 4.1$ & $93 \pm 20$ & $26 \pm 8$ & $98 \pm 14$ & $83 \pm 7.2$ & $43 \pm 1.3$ & $7.41 \pm 0.02$ \\
\hline $15^{\prime}$ & $14.6 \pm 3.8$ & $91 \pm 17$ & $27 \pm 7$ & $96 \pm 15$ & $83 \pm 6.8$ & $43 \pm 1.5$ & $7.42 \pm 0.01$ \\
\hline $30^{\prime}$ & $14.3 \pm 3.4$ & $85 \pm 13$ & $23 \pm 5$ & $92 \pm 12$ & $85 \pm 6.4$ & $42 \pm 1.6$ & $7.41 \pm 0.01$ \\
\hline $45^{\prime}$ & $13.6 \pm 2.6$ & $85 \pm 13$ & $21 \pm 5$ & $91 \pm 13$ & $84 \pm 6.5$ & $40 \pm 1.4$ & $7.40 \pm 0.01$ \\
\hline $60^{\prime}$ & $13.1 \pm 2.4$ & $84 \pm 13$ & $22 \pm 6$ & $91 \pm 12$ & $84 \pm 7.4$ & $39 \pm 2.3$ & $7.40 \pm 0.01$ \\
\hline $90^{\prime}$ & $13.8 \pm 3.3$ & $82 \pm 11$ & $20 \pm 5$ & $90 \pm 10$ & $86 \pm 6.5$ & $39 \pm 2.7$ & $7.41 \pm 0.01$ \\
\hline $120^{\prime}$ & $13.4 \pm 3.3$ & $82 \pm 12$ & $21 \pm 7$ & $90 \pm 11$ & $86 \pm 5.4$ & $40 \pm 1.9$ & $7.41 \pm 0.01$ \\
\hline $150^{\prime}$ & $13.6 \pm 3.4$ & $83 \pm 11$ & $22 \pm 6$ & $89 \pm 12$ & $84 \pm 6.6$ & $40 \pm 1.6$ & $7.41 \pm 0.02$ \\
\hline $180^{\prime}$ & $13.4 \pm 3.1$ & $84 \pm 12$ & $23 \pm 4$ & $89 \pm 12$ & $84 \pm 6.1$ & $41 \pm 2.4$ & $7.41 \pm 0.02$ \\
\hline $210^{\prime}$ & $13.5 \pm 3.4$ & $84 \pm 12$ & $23 \pm 5$ & $90 \pm 11$ & $84 \pm 8.3$ & $41 \pm 3.2$ & $7.41 \pm 0.02$ \\
\hline $240^{\prime}$ & $13.5 \pm 3.6$ & $85 \pm 12$ & $24 \pm 6$ & $92 \pm 12$ & $83 \pm 6.8$ & $41 \pm 2.8$ & $7.41 \pm 0.01$ \\
\hline
\end{tabular}

postoperative pain in patients after extrahepatic biliary tract surgery should be free from side effects such as respiratory depression, nausea, vomiting, and psychomimetic effects, but also should not increase intrabiliary pressure. Pressure increases can lead to the clinical picture of biliary colic and may even lead to a further abdominal operation to determine its cause. ${ }^{2,4,6-8}$

Nalbuphine hydrochloride, a new narcotic agonist-antagonist has been demonstrated to be a safe and effective analgesic for postoperative pain relief, ${ }^{11-13}$ and a component of balanced anaesthesia which does not affect the common bile duct pressure. $^{8,9}$ The results of the present study show that nalbuphine gives satisfactory relief of postoperative pain in patients after cholecystectomy, without affecting the intrabiliary pressure. In fact, in some patients nalbuphine slightly decreased the common bile duct pressure, a phenomenon which was also observed in our previous report. ${ }^{8}$ This decrease in common bile duct pressure was not statistically significant, but it may have been clinically beneficial to these specific postoperative patients. Although our sample size is small, nevertheless we feel that a clinically significant change in CBD pressure would have been detected with a larger sample of patients.

We recognize a possible criticism regarding the absence of a comparison with other commonly used narcotics, but since we know that these drugs cause spasm of the sphincter of Oddi, ${ }^{2}$ we decided it was unethical to use them.

Nalbuphine also appeared to have only minimal respiratory and cardiovascular effects, in the doses employed. These results suggest that the receptors responsible for analgesia may be different from those producing the excitatory effect on the sphincter of Oddi. ${ }^{13}$

In conclusion, our data support the hypothesis that the narcotic agonist-antagonist nalbuphine may have advantages over existing narcotics for postoperative pain relief in patients after extrahepatic biliary tract surgery since it provides adequate pain relief without affecting common bile pressure.

\section{References}

1 Bevan $P G$. Cholecystectomy in a surgeon. Lancet $1964 ; 1214$.

2 Economou G. Ward-McQuaid JN. A cross-over comparison of the effect of mophine, pethidine, pentazocine, and phenazocine on biliary pressure. Gut 1971; 12: 218

3 Franatovic $Y$, Arguelles JF, Romo-Salas $F$ et al. Intrabiliary pressure changes produced by narcotic drugs and inhalation anesthetics in guinea pigs. Anesth Analg 1979; 58: 120.

4 Tremblay PR, Poncelet $P$, Dihn DK. Le fentanyl et la pression dans les voies biliares. Can Anaesth Soc J 1973; 20: 747.

5 Lang $D W$, Pilon RN. Naloxone reversal of morphine-induced biliary colic. Anesth Analg 1980; 59: 619.

6 Jones RM, Fiddian-Green R, Knight PR. Narcoticinduced choledochoduodenal sphincter spasm reversed by glucagon. Anesth Analg 1980; 59: 946. 
7 McCammon RL, Stoelting RK, Madura JA. Effects of butorphanol, nalbuphine, and fentanyl on intrabiliary tract dynamics. Anesth Analg 1984; 63: 139.

8 Vatashsky $E$, Haskel $Y$. The effect of nalbuphine (Nubaine) compared to morphine and fentanyl on common bile duct pressure. Cur Ther Res 1985; 37: 95.

9 LeQuesne LP, Bolton JP. Choledocholithiasis: incidence, diagnosis and operative procedures. $I n$ : Abdominal operations. Ed. Rodney Maingot. 7th ed vol I, Appleton-Century-Crofts, New York, 1980.

10 Bussato $G$. Succinylcholine reverses spasm of the sphincter of Oddi. Anesthesiology 1979; 50: 554.

11 Tammisto T, Tigerstedt 1 . Comparison of the analgesic effects of intravenous nalbuphine and pentazocine in patients with postoperative pain. Acta Anaesthesiol Scand 1977; 21:390.

12 Beaver WT, Feise GA. A comparison of the analgesic effect of intramuscular nalbuphine and morphine in patients with postoperative pain. $\mathbf{J}$ Pharmacol Exp Ther 1978; 204: 487.

13 Errick JK, Heel RC. Nalbuphine. A preliminary review of its pharmacological properties and therapeutic eficacy. Drugs 1983; 26: 211.

\section{Résumé}

Les effets du nalbuphine sur la pression des voie biliaires ( $C B D$ ) ont été étudiés par des mesures à travers des tubes en Tle premier et second jour post-opératoire après une cholécyctectomie et cholédochotomie. Le nalbuphine d̀ des doses de $0.25 \mathrm{mg} \cdot \mathrm{kg}^{-1}$ a été injecté par voie intramusculaire chez 11 patients et les variations de la pression des voies biliaires, la fréquence cardiaque et respiratoire, la pression artérielle, la gazométrie, ont été enregistrés pour quatre heures après l'administration de nalbuphine. Les patients n'étaient pas souffrants, présentaient des pressions des voies biliaires stables et $n^{\prime}$ avaient pas de changement statistiquement significatifs de leurs signes vitaux. Ces résultats sont similaires à nos données préalables lors de l'injection intraveineuse de nalbuphine en période péri-opératoire. Il est suggéré que la nalbuphine ne change pas significativement et même peut relacher le sphincter d'Oddi, et peut ainsi être recommandé comme un analgésique sécuritaire en période post-opératoire après chirurgie biliaire extrahépatique. 